\title{
Examining the Current State of Indonesian Democracy: Elite's Perspective
}

\author{
Wijayanto $^{1}$, Budi Setiyono ${ }^{2}$, Rina Martini ${ }^{3}$ \\ \{wijayanto@live.undip.ac.id'1 , budisetiyono@lecturer.undip.ac.id², email:rinamartini13@gmail.com ${ }^{3}$ \} \\ Universitas Diponegoro, Indonesia ${ }^{1,2,3}$
}

\begin{abstract}
This study aims to examine the views of Indonesian elites on the current state of Indonesian democracy. Various studies show that Indonesia is experiencing a democratic decline. But that view immediately triggered criticism. The first criticism sees that the view contains a western bias because most of the literature that carries the opinion was written by academics from outside Indonesia who wants to impose democratic measures in their home country on the Indonesian case. The second criticism sees that view represents merely public's view that tends to be critical of the status quo and see politicians as corrupt. Departing from this situation, it is interesting to see their views about whether or not the democracy is in decline. If so, to what extent and why? As a method, this study will combine survey and in-depth interviews with 38 elites in Indonesia who are selected through a strict method. These elites have various backgrounds from politicians to academics, journalists, civil society activists, religious leaders and students. From the research, it will find a view of the latest situation of Indonesian democracy from an insider's perspective, namely the elite perspective which arguable has an important role in determining the future of the democratic consolidation in this country.
\end{abstract}

Keywords: Indonesia, Democracy, Perspective, Elite

\section{Introduction}

Various studies show that Indonesia is experiencing a democratic decline. The theories that are used to conceptualized this situation are also varied such as: "defective democracy" [1], "democratic setbacks" [2], "democratic regression" [3], "democratic deconsolidation" [1], "democratic decline" [4], "authoritarian turn" [4], "democratic backsliding" [5] and [6]; "democratic recession" [7][6]; "illiberal democracy" [3], "nondemocratic pluralism" [7][8], "recession of democracy", "authoritarian innovations" [8].

Despite that there are many scholars have argued that democracy in Indonesia is declining by using various terms, not so many of them give a clear definition as to what they mean by democratic decline. Fortunately, there are some scholars who did suggest definition. One of them is Mietzner [1] who use term "democratic deconsolidation" which he defines as "a process in which democracies gradually lose their quality over time, and which may or may not lead to a full democratic reversal" (279). In his later work with Aspinall [7], he further emphasize his argument by suggesting that democratic decline is synonymous with terms such as backsliding, recession or deconsolidation which refers to a situation where the quality of democracy quality has declined (or is declining) from a previously achieved level [7][8]. Definition also proposed by Warburton and Power [3] who theorize democratic decline as a 
process that progresses slowly which is characterized by a situation where political actors are slowly turning away from democratic values and institutions. This will not necessarily lead to authoritarianism. However, democratic regression is slowly giving birth to other types of political regimes that are not fully democratic but are also not fully dictatorial, such as illiberal democracy, competitive authoritarian systems, mixed regimes, and so on. Meanwhile, Warburton and Aspinall [3] coined a term illiberal democracy which they define as "a regime in which free and fair elections persist alongside denial of substantive political rights, such as freedom of speech or freedom to choose and practice one's religion."

The findings above have generated a lot of criticism first; one of the criticisms that have arisen against the various studies above is that they are of western bias because most of the authors are foreign observers, meaning that they are not Indonesian themselves. This then led to accusations that they were trying to impose democratic values or standards where they came from, mostly from Western Europe (western views) on Indonesia which is considered to have its own culture. Second, more than the first, it is not only biased westward but also biased by western academics. Here it is assumed that academics are a group of people who tend to over-idealize the world. Third, the research findings are considered to reflect the apathy of the average people on the behavior of the elite, especially the political elite. There is a kind of view in informal discussions among ordinary Indonesians that the Indonesian political elite are corrupt and pro-establishment. This means that they do not feel that there is a problem with the current state of democracy in Indonesia.

\subsection{Research Question}

Based on the above background, it is important to see how the views of the Indonesian people themselves and especially the elites in Indonesia regarding democracy in Indonesia. This study aims to test the existing theory by asking the question: how do the Indonesian elites themselves view the situation of democracy in Indonesia? Do the elites in Indonesia share the same opinion as the various theories above?

\section{Research Methodology}

To answer this question, this study conducted a survey and in-depth interviews with a group of elites in Indonesia who participated in democracy school activities held by LP3ES, the oldest non-governmental research institute in Indonesia in collaboration with Diponegoro University, one of the best campuses in Indonesia. This democracy school which is held for two weeks from Sunday, 16 August 2020 to Saturday, 29 August 2020, is aimed at welcoming Indonesia's 75th birthday and the 49th birthday of LP3ES on 19 August 2020.

Participants who registered were no less than 652 people consisting of DPRD members, academics, election organizers, researchers, political party administrators, journalists, civil servants, community leaders and students from all over Indonesia, from Aceh to Papua, Kalimantan, Sulawesi, Bali to Nusa Tenggara. Of all applicants, only 38 were selected taking into account the diversity of professional backgrounds, domicile (Java and outside Java), age and gender.

In this case the survey was conducted on August 16, 2020 via Google sheet. Meanwhile, interviews with the focus group discussion method were carried out by zooming. 


\section{Results and Discussion}

\subsection{Democracy Schools as a Medium for Building Dialogue}

The School of Democracy, which is collaboration between UNDIP and LP3ES was held simply: to build a forum that could be a bridge for progressive actors from various backgrounds to meet and have dialogue. The diversity of backgrounds becomes wealth. This is because often each political actor speaks within the limitations of their respective perspectives which are influenced by their position. This then creates a situation where each actor blames each other. Academics are adamant that the political elites have transformed into a group of predatory oligarchs that have hijacked democracy in a direction that is very dangerous to the future of the nation. But on the other hand, we find that political parties are an institution that has barely changed after two decades of reform with all its problems: dynastic politics, slow regeneration, elite corruption and young politicians competing with old practices.

The harsh criticism of the scientists from inside his campy ivory tower had absolutely no effect on the political praxis that took place "out there." If these two actors happen to meet, as we have seen in various talk shows on the small screen, what happens is a stifling scene. The two of them seemed to be speaking from completely different worlds. The heated debate between Emil Salim and Arteria Dahlan can be an example. In one conversation on television, Arteria insisted that his position in supporting the revision of the KPK Law was a manifestation of the people's will because the majority of DPR members elected by the people agreed with this. Emil Salim challenged whether members of the council could claim people's representatives if the election was covered by money politics to win votes? The debate then reached a deadlock which led to criticism of Arteria, who was considered rude.

But the question is, is it really that simple? Aren't people often looking for justification on television instead of the truth? Furthermore, do we not find that often sharp divisions often occur between those within the circle of power and those outside it? In a satirical tone, Mahfud MD, before becoming a minister, once said, "Even angels will become devils if they enter our system". Mahfud conveyed this description in 2013 to comment on the statement of the Minister of Home Affairs Gamawan Fauzi that 50 percent or 278 of our regional heads were involved in corruption.

How can Mahfud's view be explained? The views of the French philosopher and sociologist Pierre Bourdieu can help explain this through his theory of the arena known as "field theory". The essence of the argument is that the arena is a locus that has its own logic that will shape and influence the social action of the subjects in it. Since each actor moves according to the logic of their respective arenas and sees from the perspective of that arena, it is not surprising that they see in different ways and internalize a different habitus. In this regard, Bourdieu divides the arenas into the academic arena, the political arena, and the journalistic arena. Then, because each actor tends to see problems in their narrow perspective, one platform that can become a bridge for people from different arenas to meet each other and have dialogue is important. Borrowing Habermas's idea, dialogue is a method for finding communicative ratios. Dialogue builds mutual understanding, stimulates critical thinking and presents fresh new ideas. First of all to formulate the problem of democratic consolidation that we are facing coldly, honestly, without haste. This includes questioning what we consider normal and abnormal in our political civilization. 


\subsection{Profile of Respondents}

The respondents of the research is 38 participants of the Sekolah Demokrasi of UNDIP and LP3ES. Those 38 respondents can be further described as follows.

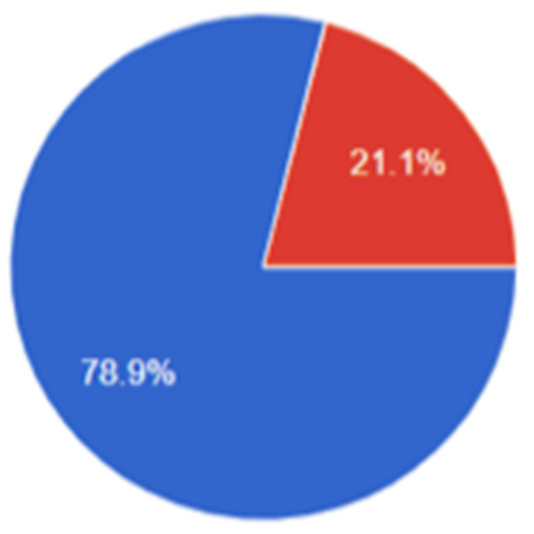

Fig. 1. The Gender

Based on gender, $78.9 \%$ of the respondents are male while $21.1 \%$ other is female. Meanwhile based on profession, it can be seen in figure 2 .

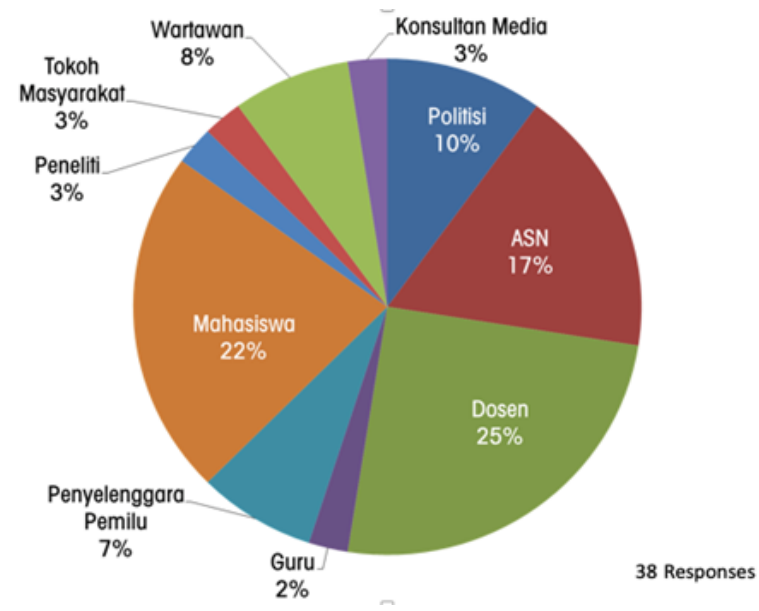

Fig. 2. Profession

From the figure 2 above, it can be seen that the respondents are diverse. There are $25 \%$ lecturers, $22 \%$ students, $17 \%$ civil servant, $10 \%$ politicians, $8 \%$ journalists, $7 \%$ election committee's members, $3 \%$ media consultant, public figures, researchers and $2 \%$ teachers. The diversity in term of profession is also in line with the diversity in term of place of origin as the participants came from across Indonesian archipelago as demonstrated in figure 3. 


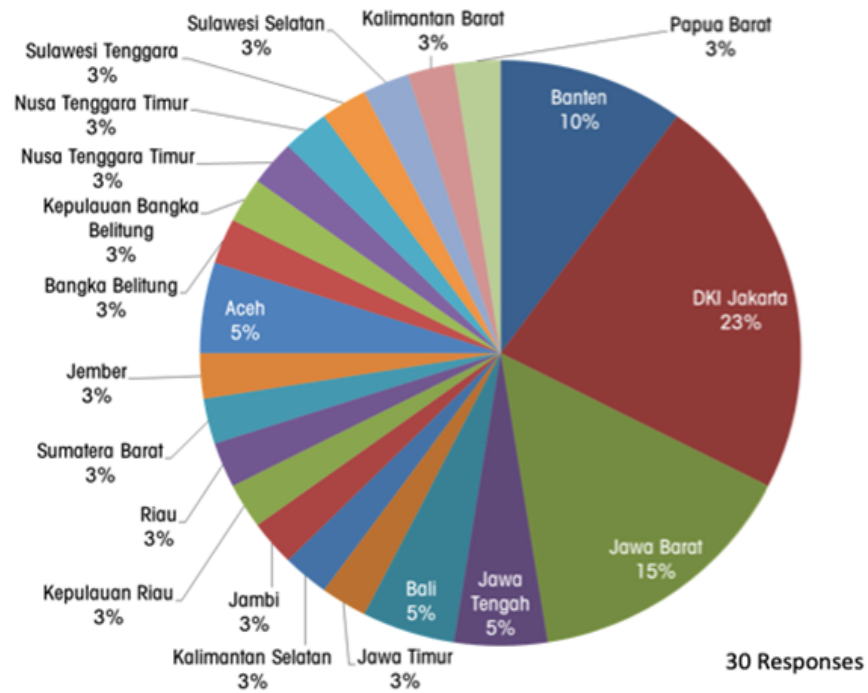

Fig. 3. Place of Origin

From figure 3, we can see that most of participants come from Java (56\%) which consists of Banten (10\%), Jakarta (23\%), West Java (15\%), East Java (3\%) and Central Java (5\%). However, almost half of them (47\%) come from the islands outside Java from Papua to Borneo to Celebes, to Nusa Tenggara, Bangka, Aceh and others.

\subsection{Elite Views on Democracy in Indonesia}

From the survey, it was found as follows: most of the respondents saw that democracy in Indonesia is in a gloomy situation in the form of setbacks (44.7\%), stagnation / stagnation (23.7\%) and some even think that we are under authoritarianism (28.9\%). Only $2.7 \%$ of respondents rated our democracy as progressing. Furthermore, there are 21 problems that mark the decline of democracy in Indonesia: money politics in elections $(100 \%)$, stalled regeneration of political parties $(94.7 \%)$, populism and identity politics $(86.8 \%)$, loss of opposition (92.1\%), political corruption (100\%), fake news and hate speech (97.4\%), low political literacy $(92.1 \%)$, low media literacy $(92.1 \%)$, weak civil society $(89.5 \%)$, low quality of elections (100\%), partisan mass media (89.5\%), low government effectiveness $(94.7 \%)$, low political participation $(100 \%)$, threats to freedom of speech $(94.7 \%)$, threats to freedom of association $(94.7 \%)$, immunity to human rights violators $(86.8 \%)$, economic inequality $(94.7 \%)$, discrimination against minorities $(97.4 \%)$, tolerance or advocacy against violence (94.6\%), cyber terror against the critical group (92.1\%), the criminalization of the critical group $(92.1 \%)$.

In addition to the survey above, democracy problems that emerged expressed by participants in democracy schools included:

1. Dynastic politics: dynastic politics is one of the serious problems of democracy that was expressed by the discussion participants and became the forum's agreement. Specifically, the area that is considered to be the locus for the implementation of dynastic politics is Banten, which was practiced by the families of the queens of Atut and Solo, which is 
associated with the advancement of President Jokowi's son Gibran in the regional elections which has the potential to become a single candidate.

2. Centralization of political parties amidst the spirit of decentralization so that cadres promoted by parties in the regions are often popular with the DPP but do not have roots in the regions. The result is the absence of local accountability and equality. The result is the dependence of local parties on the central party.

3. The unclear ideology of political parties makes them like interest groups moving for short-term political pragmatism.

4. There is no democracy and equality within political parties, even though they are expected to be the main pillars of democracy.

5. The absence of financial transparency of political parties, especially during general elections.

6. Political oligarchy: the accumulation of power and wealth in the hands of a few elites is one thing that is seen as another democratic problem. These rich and powerful elites use it to buy votes in elections so that those who are elected are not necessarily a reflection of the people's votes. Including the oligarchy at the local level.

7. Media oligarchy: control of the mass media by only a few people, some of whom are politicians, is seen as another problem that weakens the function of the media as the guardian dog of democracy.

8. Neutrality: there is a dilemma among ASNs because although they are legally required to be neutral, in practice they are often asked to support the incumbent.

9. Buzzers and cyber troops: the perpetrators of manipulating public opinion for political purposes. They do not claim to be paid for the dissemination of that opinion.

10. Weak protection of personal data and even many cases of personal data hacking are experienced by them because of their political activism.

Meanwhile, based on the focus group discussion held for two weeks, it was found.

The 31 problem above can actually be grouped into 4 big concepts: structural, institutional, cultural and agency which can be described in more detail as follows:

1. Structural: Political corruption, political oligarchy, media oligarchy, economic inequality.

2. Institutional: money politics in elections, stalled regeneration of political parties, internal party feudalism, absence of political party financial transparency, neutrality of ASN, centralization of political parties, no party ideology, no protection of personal data, low quality of elections, partisan mass media, low levels of governance effectiveness.

3. Cultural: dynastic politics, fake news and hate speech, low political literacy, low media literacy, buzzers for manipulation of public opinion, low political participation, discrimination against minorities, populism and identity politics.

Agency: Loss of opposition, threat of freedom of opinion, threat of freedom of association, immunity against human rights violators, tolerance or advocacy against violence, cyber terror against critical groups, criminalization of critical groups, cyber terror.

\section{Conclusion}

This study examines the elite's views on Indonesian democracy. It found that unlike the stereotype that the elites are keener to the establishment status quo; this study suggested that Indonesian elites also perceived Indonesian democracy in decline (44\%). Some of them are more moderate by suggesting that our democracy is in the stage stagnation (23.7\%). However, 
some even think that we are under authoritarianism system $(28.9 \%)$. It is only $2.7 \%$ of respondents rated our democracy as progressing.

Meanwhile, in total there are 31 problems that mark the decline of democracy in Indonesia. Twenty one of them were based on surveys which are: money politics in elections $(100 \%)$, stalled regeneration of political parties $(94.7 \%)$, populism and identity politics $(86.8 \%)$, loss of opposition $(92.1 \%)$, political corruption $(100 \%)$, fake news and hate speech $(97.4 \%)$, low political literacy $(92.1 \%)$, low media literacy $(92.1 \%)$, weak civil society $(89.5 \%)$, low quality of elections $(100 \%)$, partisan mass media $(89.5 \%)$, low government effectiveness $(94.7 \%)$, low political participation $(100 \%)$, threats to freedom of speech (94.7\%), threats to freedom of association (94.7\%), immunity to human rights violators $(86.8 \%)$, economic inequality $(94.7 \%)$, discrimination against minorities $(97.4 \%)$, tolerance or advocacy against violence $(94.6 \%)$, cyber terror against the critical group $(92.1 \%)$, the criminalization of the critical group (92.1\%). While 10 others appeared in the focused discussion, including: dynastic politics, centralization of political parties, no party ideology, no equality and democracy within the party, the absence of political party financial transparency, political oligarchy, media oligarchy, ASN neutrality, buzzers for manipulation public opinion and no protection of personal data. Those thirty-one problems above can actually be grouped into 4 major problems: structural, institutional, cultural and agency.

Despite its interesting finding, this survey does not claim to represent the views of all Indonesian citizens, but at least it can provide "insight" about the situation of democracy in Indonesia from the perspective of some elites, be it intellectual elites, political elites, civil society elites, election organizers, students and ASN who are part of the strata elites from Indonesian society, who were elected as participants of the LP3ES democracy. Therefore, this study suggests that further research with more representative number of samples should be taken for the next study.

\section{References}

[1] M. Mietzner, "Coercing Loyalty: Coalitional Presidentialism and Party Politics in Jokowi's Indonesia," Contemp. Southeast Asia, pp. 209-232, 2016.

[2] V. R. Hadiz, "Indonesia's year of democratic setbacks: Towards a new phase of deepening illiberalism?," Bull. Indones. Econ. Stud., vol. 53, no. 3, pp. 261-278, 2017.

[3] E. Aspinall and E. Warburton, "Indonesia: The Dangers of Democratic Regression," in Third International Conference on Social and Political Sciences (ICSPS 2017), 2017.

[4] T. P. Power, "Jokowi's authoritarian turn and Indonesia's democratic decline," Bull. Indones. Econ. Stud., vol. 54, no. 3, pp. 307-338, 2018.

[5] E. Aspinall and W. Berenschot, Democracy for Sale: Pemilihan Umum, Klientelisme, dan Negara di Indonesia. Yayasan Pustaka Obor Indonesia, 2019.

[6] E. Aspinall and M. Mietzner, "Indonesia's Democratic Paradox: Competitive Elections Amidst Rising Illiberalism," Bull. Indones. Econ. Stud., vol. 55, no. 3, pp. 295-317, 2019.

[7] W. Aspinall, E., \& Berenschot, Democracy for Sale: Pemilihan Umum, Klientelisme, dan Negara di Indonesia. Yayasan Pustaka Obor Indonesia, 2019.

[8] E. Aspinall and M. Mietzner, "Southeast Asia's Troubling Elections: Nondemocratic Pluralism in Indonesia," J. Democr., vol. 30, no. 4, pp. 104-118, 2019. 